\title{
Barilius profundus, a new cyprinid fish (Teleostei: Cyprinidae) from the Koladyne basin, India
}

\author{
M. Dishma1 \& W. Vishwanath ${ }^{2}$ \\ 1,2 Department of Life Sciences, Manipur University, Canchipur, Manipur 795003, India \\ Email: ${ }^{1}$ dishma27@gmail.com, ${ }^{2}$ wvnath@gmail.com (corresponding author)
}

Date of publication (online): 26 February 2012 Date of publication (print): 26 February 2012 ISSN 0974-7907 (online) | 0974-7893 (print)

Editor: K. Rema Devi

Manuscript details:

Ms \# 02838

Received 15 June 2011

Final received 05 January 2012

Finally accepted 30 January 2012

Citation: M. Dishma \& W. Vishwanath (2012) Barilius profundus, a new cyprinid fish (Teleostei: Cyprinidae) from the Koladyne basin, India. Journal of Threatened Taxa 4(2): 2363-2369.

Copyright: (c) M. Dishma \& W. Vishwanath 2012. Creative Commons Attribution 3.0 Unported License. JoTT allows unrestricted use of this article in any medium for non-profit purposes, reproduction and distribution by providing adequate credit to the authors and the source of publication.

Author Details: M. DISHMA is a junior research fellow under a project funded by the Department of Science \& Technology, New Delhi. He is working on the inventory of the bariline and cobitid fishes of northeastern India. $\mathrm{He}$ is undergoing $\mathrm{PhD}$ on a relevant topic in the Department of Life Sciences, Manipur University. Dr. W. VISHWanath is a Professor in the Department of Life Sciences, Manipur University. His field of specialization is fish and fisheries. He is presently engaged in taxonomy and systematics of freshwater fishes of northeastern India.

Author Contribution: See end of this article

Acknowledgements: The authors are gratefu to the Department of Science \& Technology, New Delhi (Project No. SR/SO/AS-50/2008) for financial support.
Abstract: Barilius profundus, a new species of bariline cyprinid fish is described from the Koladyne River, Mizoram, India. It is distinguished from congeners in having the following combination of characters: great body depth at dorsal-fin origin (32.0-37.3\% SL), 17-18 pre-dorsal scales, 7-10 dark blue bars on the sides of the body, 30-32 + 2-3 lateral line scales, $1 / 27 / 1 / 21 / 2$ lateral transverse scales and 12 circumpeduncular scales. Key to species of Barilius of northeastern India is provided.

Keywords: Bariline fish, Mizoram, new species.

\section{INTRODUCTION}

Fishes of the genus Barilius Hamilton are characterised by a compressed body, blue-black bars or spots on the body and dorsal fin inserted behind the middle of the body (Hamilton 1822). The members of this genus are inhabitants of medium to fast flowing torrential mountain streams of China, western Asia, South and mainland South-east Asia. Thirteen species of the genus are hitherto known from the Eastern Himalaya region (Vishwanath et al. 2010). They are: B. ngawa Vishwanath \& Manojkumar, B. dogarsinghi Hora, B. chatricensis Selim \& Vishwanath, B. lairokensis Arunkumar \& Tombi from the Chindwin drainage; B. barila (Hamilton), B. bendelisis (Hamilton), B. tileo (Hamilton), B. shacra (Hamilton), B. vagra (Hamilton), B. barna (Hamilton), B. dimorphicus Tilak \& Husain, $B$. radiolatus Gunther, and $B$. bonarensis Chaudhuri from the GangaBrahmaputra drainage. The Koladyne River in Mizoram, northeastern India, is a drainage connected neither with the Ganga-Brahmaputra nor the Chindwin drainages. Its icthyofauna is poorly explored. Collections from the river (also known as Kaladan or Chhimtuipui) include an undescribed species of Barilius which is herein described as a new species.

\section{MATERIALS AND METHODS}

Measurements were made point to point on the left side of specimens wherever possible with dial calipers to the nearest $0.1 \mathrm{~mm}$. The colour in fresh specimens was noted before fixation and preservation in $10 \%$ formalin. Counts and measurements follow Kottelat (1990) and lateral line scale count, Kottelat (2001). Head length (HL) and anatomical measurements are expressed as proportions of standard length (SL) and subunits of head as proportions of head length (HL). Osteological structures were observed in a cleared and alizarin-stained specimen 


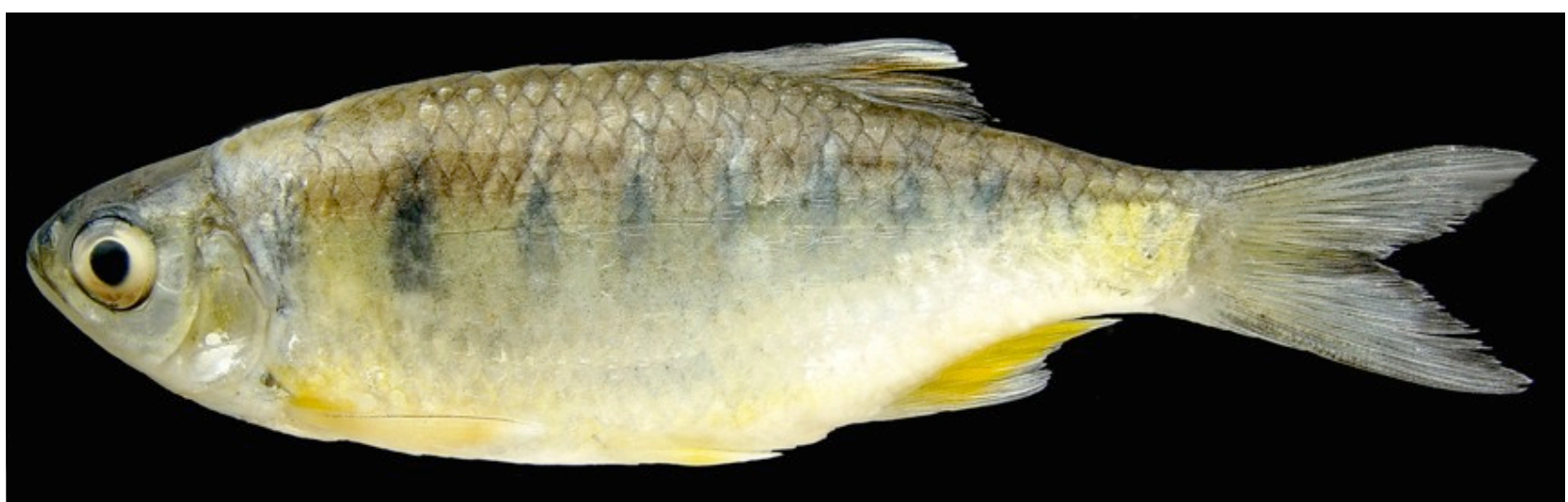

Image 1. Barilius profundus sp. nov., side view of paratype, MUMF 27021, 69.9mm SL

following Hollister (1934). Vertebral counts follow Weitzman (1962). Fin rays were counted under a stereo-zoom light microscope. Type specimens are deposited in the Manipur University Museum of Fishes (MUMF).

\section{Barilius profundus sp. nov.}

(Image 1)

\section{Type material}

Holotype: $24 . x i i .2009, \quad 22^{0} 23^{\prime} \mathrm{N} \quad \& \quad 92^{0} 57^{\prime} \mathrm{E}$, $71.1 \mathrm{~mm}$ SL; Koladyne River at Kolchaw, Lawntlai District, Mizoram, India, coll. Nebeshwar and party, MUMF 27001.

Paratypes: 4 exs., 55.2-67.7 mm SL, data as for holotype, MUMF 27002-27005; 8 exs., 30.xi.2008, 50.9-69.9 mm SL; Koladyne River at Kolchaw, Lawntlai District, Mizoram, India, coll. Nebeshwar \& party, MUMF 27021-27028. One paratype (MUMF $27005,54.5 \mathrm{~mm} \mathrm{SL}$ ) dissected for osteology.

\section{Diagnosis}

A species of Barilius with the following combination of characters: great body depth at dorsal-fin origin (32.0-37.3\% SL); $17-18$ pre-dorsal scales; 7-10 dark blue bars against faintly brown to yellowish-cream background of body, width of bar narrower than interspace width; lateral line complete with 30-32 + 2-3 scales; eye diameter (38.3-42.9\% HL), predorsal length (58.9-64.0\% SL); dorsal-fin length (21.6-25.7\% SL); 1/27/1/21/2 lateral transverse scales; 12 circumpeduncular scales; and 35 vertebrae.

\section{Description}

Morphometric data are shown in Table 1 and Appendix 1. Body compressed, abdomen rounded. Dorsal profile in front of dorsal-fin origin relatively straight, gently sloping downward towards base of caudal peduncle. Ventral profile slightly curved till pectoral-fin origin, then straight up to anal-fin origin, thereafter sloping dorsally to end of caudal peduncle. Muscular pads present at base of pectoral and pelvic fins.

Head moderately compressed; shorter than wide. Snout blunt, profile dorsally curved and rounded when viewed laterally, length shorter than interorbital distance. Eyes large, slightly bulging (convex), visible both from dorsal and ventral sides of head, situated in anterior half of head, diameter smaller than interorbital distance. Interorbital space slightly arched. Mouth terminal, obliquely directed upwards. Gape of mouth reaches anterior margin of orbit. Tubercles on snout and lower jaw poorly developed.

Barbels two pairs, short. One pair each of rostral and maxillary. Lips thin. Nostrils almost at level of upper margin of eye, distinctly nearer to anterior margin of eye than tip of snout. Jaws equal in length. Lower jaw without symphysial knob.

Dorsal fin inserted posterior to pelvic-fin origin with ii, $7 \frac{1}{2}$ rays and closer to caudal-fin base than tip of snout; longer than pelvic and anal fin; tip of last branched ray extending to middle of anal fin base. Pectoral fin with i,11 rays, shorter than head length; their tips pointed or nearly so; not reaching pelvic-fin origin. Pelvic fin with i, 8 rays, its origin much nearer to anal-fin origin than pectoral-fin origin, shorter than head length and pectoral fin; pelvic fin not reaching 
Table 1. Morphometric data for Barilius profundus sp. nov. $(n=13)$

\begin{tabular}{|c|c|c|c|c|}
\hline & $\begin{array}{c}\text { Holotype } \\
\text { MUMF } 27001\end{array}$ & Range* & Mean & SD \\
\hline Standard length (mm) & 71.1 & $50.9-71.1$ & & \\
\hline \multicolumn{5}{|l|}{ In $\%$ of standard length } \\
\hline Body depth at dorsal fin origin & 32.0 & $32.0-37.3$ & 34.6 & 2.5 \\
\hline Head length & 18.6 & $18.6-21.0$ & 19.8 & 1.0 \\
\hline Predorsal length & 59.9 & $58.9-64.0$ & 61.4 & 3.9 \\
\hline Prepelvic length & 51.6 & $45.8-62.3$ & 54.0 & 4.5 \\
\hline Pre-anus length & 67.8 & $67.8-74.6$ & 71.2 & 4.6 \\
\hline Preanal length & 70.6 & $70.6-76.3$ & 73.4 & 4.6 \\
\hline Prepectoral length & 28.1 & $26.9-30.2$ & 28.5 & 1.9 \\
\hline Pectoral fin length & 20.8 & $20.8-24.5$ & 22.6 & 1.2 \\
\hline Pelvic fin length & 13.9 & $13.9-17.6$ & 15.7 & 0.8 \\
\hline Dorsal fin height & 21.6 & $21.6-25.7$ & 23.6 & 1.4 \\
\hline Dorsal fin base length & 16.1 & $14.9-17.5$ & 16.2 & 1.3 \\
\hline Anal fin length & 16.6 & $16.6-20.4$ & 18.5 & 1.0 \\
\hline Caudal peduncle length & 14.0 & $11.1-15.4$ & 13.2 & 1.0 \\
\hline Caudal peduncle depth & 11.6 & $11.4-15.6$ & 13.5 & 0.9 \\
\hline \multicolumn{5}{|l|}{ In $\%$ of head length } \\
\hline Snout length & 43.1 & $34.9-43.1$ & 39.0 & 0.6 \\
\hline Eye diameter & 40.1 & $38.3-42.9$ & 40.6 & 0.3 \\
\hline Interorbital distance & 50.0 & $45.2-53.3$ & 49.2 & 0.6 \\
\hline Maximum head width & 67.4 & $58.5-79.2$ & 68.8 & 1.3 \\
\hline Head height at supraoccipital & 118.9 & $111.6-136.8$ & 124.2 & 1.7 \\
\hline \multicolumn{5}{|l|}{ Counts } \\
\hline D rays & ii, $71 / 2$ & ii, $71 / 2$ & & \\
\hline$P$ rays & $\mathrm{i}, 11$ & $\mathrm{i}, 11$ & & \\
\hline$V$ rays & $\mathrm{i}, 8$ & $\mathrm{i}, 8$ & & \\
\hline A rays & ii, $10 \frac{1}{2}$ & ii, $101 / 2$ & & \\
\hline C rays & $\mathrm{i}, 9+8, \mathrm{i}$ & $\mathrm{i}, 9+8, \mathrm{i}$ & & \\
\hline L.I & $32+2$ & $30-32+2-3$ & & \\
\hline L.tr. & $1 / 2 / 7 / 1 / 21 / 2$ & $1 / 2 / 7 / 1 / 21 / 2$ & & \\
\hline Predorsal scales & 18 & $17-18$ & & \\
\hline Circumpeduncular scales & 12 & 12 & & \\
\hline Transverse bands on body & 8 & $7-10$ & & \\
\hline
\end{tabular}

L.I - lateral line longitudinal scales; L.tr. - lateral transverse scales; * - measurements of all individuals provided in Appendix 1.

anal opening. Anal-fin origin just below base of last dorsal fin ray, with ii, 101/2 rays; not reaching caudal peduncle when adpressed; fin margin concave. Anal fin shorter than head length. Anal opening located immediately anterior to anal-fin origin. Caudal fin deeply forked with i, 9+8, i principal rays, both upper and lower lobes equal in length.

Scales moderate. Circumpeduncular scales 12, lateral transverse scale $1 / 27 / 1 / 2 \frac{1}{2}$. Lateral line complete with $30-32+2-3$ scales. Vertebrae $18+17=35$ including complex vertebra.

Colour: In a fresh specimen, dorsal and dorsolateral surfaces of head and body faintly brown, ventral portion anterior to pelvic-fin origin silver coloured. Belly creamy to golden yellowish and with 7-10 dark blue bars on the sides; first anterior-most dark blue bar extends beyond lateral line, sometimes first two or three anterior-most bars touch lateral line. Dorsal 


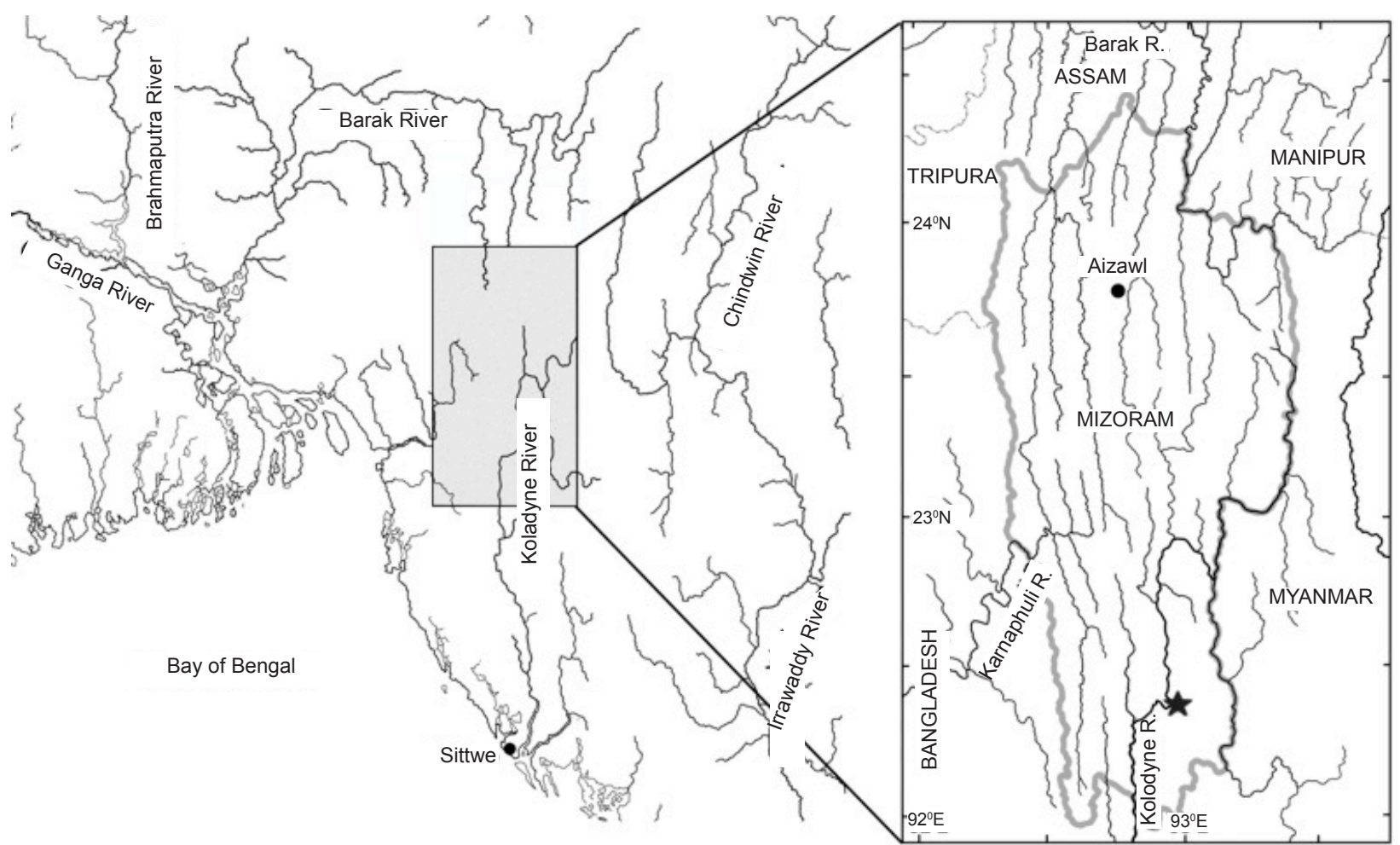

Figure 1. Map showing type locality of Barilius profundus sp. nov. indicated as a star.

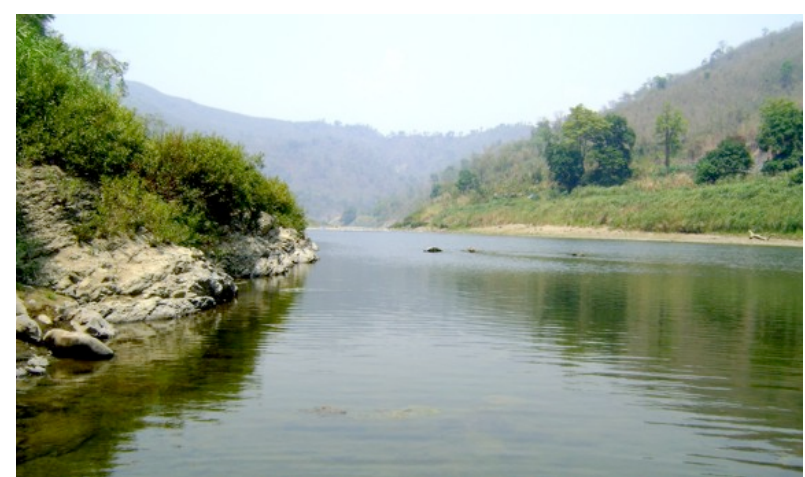

Image 2. Koladyne River at Kolchaw, Mizoram, habitat of Barilius profundus sp. nov.

fin hyaline with a row of elongated black marks. Pectoral, pelvic and anal fins golden yellow with hyaline distal margins. Caudal fin edged with black, faintly yellowish-green at the base.

In $10 \%$ formalin, body creamy, slightly dark dorsally. Dorsal fin hyaline with a row of elongated black marks. Caudal fin hyaline, edged with black. Pectoral, anal and ventral fins hyaline without dark bands.

\section{Etymology}

The species name 'profundus' (Latin, meaning deep) is in reference to its great body depth, an adjective.

\section{Distribution}

Presently known only from the Koladyne River at Mizoram (Fig. 1, Image 2).

\section{DISCUSSION}

Barilius profundus sp. nov. is close to its nearest congeners, $B$. dogarsinghi and B. barna in having a dorsal fin with $7 \frac{1}{2}$ branched rays and a pelvic fin with eight branched rays. However, the new species differs from $B$. dogarsinghi in having greater body depth at dorsal-fin origin (32.0-37.3\% SL vs. 24.8-30.0), eye diameter (38.3-42.9\% HL vs. 29.2-33), and branched anal-fin rays (101/2 vs. $\left.9 \frac{1}{2}\right)$; lesser pre-dorsal scales (17-18 vs. 20$)$, lateral line scales $(30-32+2-3$ vs. $37-40+2)$. It differs from $B$. barna in having greater body depth at dorsal-fin origin (32.0-37.3\% SL vs. 29.0-30.8); presence (vs. absence) of barbels; longer 
predorsal distance (58.9-64.0\% SL vs. 53.9-54.9), anal-fin distance (16.6-20.4\% SL vs. 13.3-15.1); shorter caudal peduncle (11.4-15.6\% SL vs. 16.116.9); more predorsal scales (17-18 vs. 15-16); lesser lateral line scales $(30-32+2-3$ vs. $36-39+2-3)$, and branched pectoral-fin rays (11 vs. 12).

Barilius profundus sp. nov. differs from B. barila, B. tileo, B. shacra and B. vagra in having greater body depth at dorsal-fin origin $32.0-37.3 \% \mathrm{SL}$ (vs. 23.4-24.0 in B. barila, 29.9 in B. tileo, 22.2-23.2 in B. shacra and 25.2-26.7 in $B$. vagra), 17-18 predorsal scales (vs. 22 in B. barlia, 28 in B. tileo, $22-25$ in $B$. shacra and 21-22 in B. vagra) and 30-32+2-3 lateral line scales (vs. $40-42+2-3$ in B. barila, $59+4$ in $B$. tileo, 59-70 in B. shacra and 40-42+3 in B. vagra). Barilius profundus sp. nov. further differs from $B$. bendelisis in having greater body depth at dorsal-fin origin (32.0-37.3\% SL vs. $22.1-26.1), 30-32+2-3$ lateral line scales (vs. 39-42+2-4), scales without dark spot (vs. with dark spot); from B. radiolatus in having greater body depth at dorsal-fin origin (32.0 $37.3 \%$ SL vs. 22.2$), 30-32+2-3$ lateral line scales (vs. 58), ventral fin not reaching vent (vs. reaching vent); from $B$. bonarensis in having greater body depth at dorsal-fin origin (32.0-37.3\% SL vs. 21.722.2), 30-32+2-3 lateral line scales (vs. 47); from $B$. dimorphicus in having greater body depth at dorsal-fin origin (32.0-37.3\% SL vs. 24.9-28.8), 30-32 + 2-3 lateral line scales (vs. 60-66), 17-18 predorsal scales (vs. 25-27). The new species differs from B. ngawa, $B$. chatricensis and B. lairokensis in having greater body depth at dorsal-fin origin (32.0-37.3\% SL vs. 24.8-28.3 in B. ngawa, 23.2 in B. chatricensis, 25.5 in B. lairokensis), 17-18 predorsal scales (vs. 21-22 in $B$. ngawa, 15 in B. chatricensis, 21 in B. lairokensis), 30 $32+2-3$ lateral line scales $(40-41+2-3$ in $B$. ngawa, $36+2$ in B. chatricensis, $41+3$ in B. lairokensis).

In case of Barilius radiolatus, $B$. bonarensis, $B$. dimorphicus and $B$. shacra, the specimens are not available for examination. Thus, the lateral line scale counts used for comparison are from the published data, which might include the pored scales behind the hypural plate which are normally $2-3$. However, the differences in the counts are great and we can confirm these to be different.

Kar \& Sen (2007) listed three species of Barilius viz., B. barna, B. vagra and B. shacra from the Koladyne River basin but they neither gave descriptions of the species nor mentioned where the collections were eventually deposited. The three species are not represented from the basin in our collections. However, we compared $B$. profundus sp. nov. with B. barna, $B$ vagra from the Dikrong and Barak rivers (both Brahmaputra drainage) respectively and with $B$. shacra using the published data. As noted above, the three species are readily distinguishable from the new species.

\section{Comparative material}

Barilius barila: MUMF 5049, 5051, 83.2-89.5 mm SL, Khuga River, Churchandpur, Manipur, India. Barilius barna: MUMF 27061-27064, 73.0-83.1 mm SL, Dikrong River, Arunachal Pradesh, India.

Barilius bendelisis: MUMF 27067-27068, 100.3105.8 mm SL, Iyei River, Noney, Manipur, India; MUMF 27069-27072, 72.4-105 mm SL, western side of Maram Khulen \& Laironching, Manipur, India.

Barilius chatricensis: MUMF 503/1 (holotype), $86.4 \mathrm{~mm}$ SL, Chatrickong River, Ukhrul District, Manipur, India. $150 \mathrm{~km}$ from Imphal. Additional data from Selim \& Vishwanath (2002).

Barilius dogarsinghi: MUMF 207-210, 52.9-72.2 $\mathrm{mm}$ SL, Chakpi stream, Manipur, India.

Barilius ngawa: MUMF 149 (holotype), 96.5mm SL, Sherou River (tributary of Manipur river), $83 \mathrm{~km}$ south of Imphal, Manipur, India; MUMF 2705627058, 80.0-82.9 mm SL, Singda, Manipur, India.

Barilius lairokensis: MUMF 27075, $105.0 \mathrm{~mm}$ SL, Moreh bazar, Moreh, Chandel District, Manipur, India.

Barilius vagra: MUMF 4091-4093, 88.0-107.3 mm SL, Barak River, Vanchengphai, Tamenglong District, Manipur, India.

Barilius tileo: MUMF 27076, $128.1 \mathrm{~mm}$ SL, Umtrao River, Byrnihat, Norbong, Ribhoi District, Assam, India.

Barilius dimorphicus: Data from Tilak \& Husain (1990).

Barilius bonarensis: Data from Chaudhuri (1912).

Barilius shacra: Data from Talwar \& Jhingran (1991).

Barilius radiolatus: Data from Gunther (1868). 
Keys to species of the genus Barilius of northeastern India

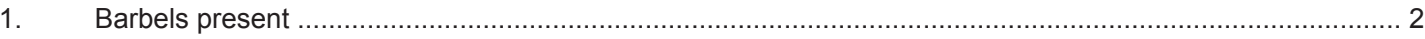

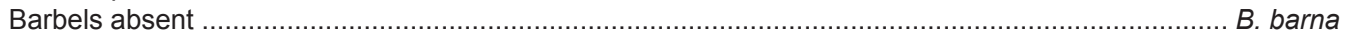

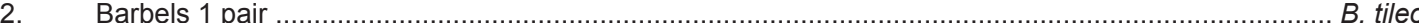

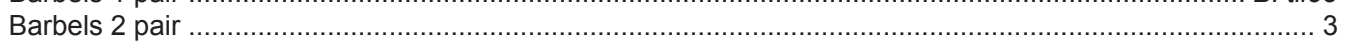

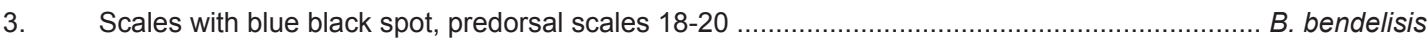

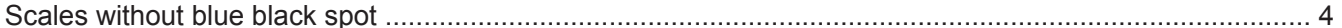

4. Predorsal scales 15-18

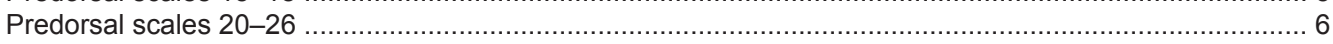

5. Lateral line scales $32-35$, depth of body $32.0-37.3 \% \mathrm{SL}$

B. profundus sp. nov. Lateral line scales 38, depth of body 24.6-29.2 \% SL ……........................................... B. chatricensis

6. Mandibular knob not distinct, dorsal fin with a transverse blue black band ............................ B. dogarsinghi Mandibular knob distinct, dorsal fin without transverse band .................................................................. 7

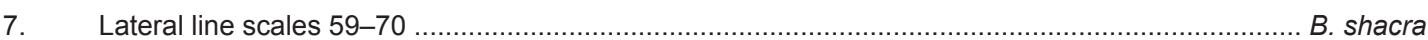

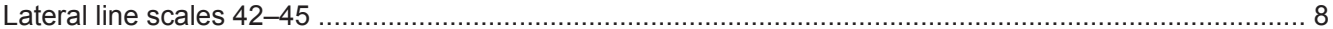

8. Pectoral fin as long as head, body with 14-15 bars .................................................................. B. barila

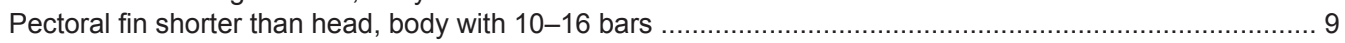

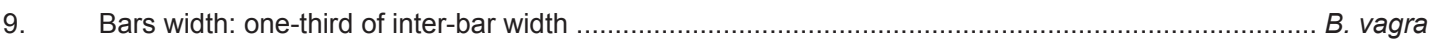

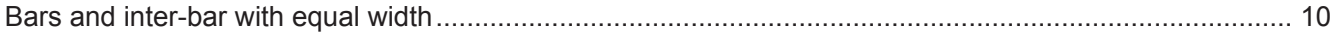

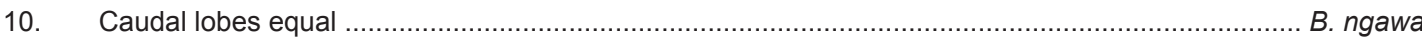

Caudal lobes unequal, lower lobe longer than the upper ...................................................... B. lairokensis

\section{REFERENCES}

Chaudhuri, B.L. (1912). Descriptions of some new species of freshwater fishes from north India. Records of the Indian Museum 7(5): 437-444+pls. 38-41.

Günther, A. (1868). Catalogue of The Fishes in The British Museum. Department of Zoology, British Museum (Natural History), London 7: i-xx+1-512.

Hamilton, F. (1822). An Account of The Fishes Found in The River Ganges and Its Branches. Archibald Constable, Edinburg and Hurst, Robinson, London, 405pp.

Hollister, G. (1934). Clearing and dying fishes for bone study. Zoologica 12: 89101.

Kar, D. \& N. Sen (2007). Systematic list and distribution of fishes in Mizoram, Tripura and Barak drainage of Northeastern India. Zoos' Print Journal 22(3): 2599-2607.

Kottelat, M. (1990). Indochinese Nemacheilines, A Revision of Nemacheiline Loaches (Pisces: Cypriniformes) of Thailand, Burma, Laos, Cambodia and southern Vietnam. Verlag, Dr. Friedrich Pfiel, Munchen, 262pp.

Kottelat, M. (2001). Fishes of Laos. Wildlife Heritage Trust, Colombo, 198pp.

Selim, K. \& W. Vishwanath (2002). A new cyprinid fish species of Barilius Hamilton from the Chatrickong River, Manipur, India. Journal of the Bombay Natural History Society 99(2): 267-270.

Talwar, P.K. \& A.G. Jhingran (1991). Inland Fishes of India and Adjacent Countries - Vol. 1, Oxford \& IBH Publishing Co. Pvt. Ltd., New Delhi, 541pp.

Tilak, R. \& A. Husain (1990). Description of a new cyprinid, Barilius dimorphicus (subfamily: Rasborinae) from Rajaji National Park, Uttar Pradesh. Journal of the Bombay Natural History Society 87(1): 102-105.

Vishwanath, W., H.H. Ng, R. Britz, L.K. Singh, S. Chaudhry \& K.W. Conway (2010). The status and distribution of freshwater fishes of the Eastern Himalaya region, pp. 22-41. In: Allen, D.J., S. Molur \& B.A. Daniel (compilers). The Status and Distribution of Freshwater Biodiversity in The Eastern Himalaya. IUCN, Cambridge, UK and Gland, Switzerland, viii $+89 \mathrm{pp}$.

Weitzman, S.H. (1962). The osteology of Brycon meeki, a generalized Characid fish, with an osteological definition of the family. Standford Ichthyological Bulletin 8(1): $1-77$.
Author Contribution: The study: MD survey, collection, morphometric and anatomic study of bariline fishes of northeastern India and their phylogenetics; WV supervision of taxonomy and phylogeny of freshwater fishes of northeastern India. Current paper: MD detailed examination of the bariline fishes of the Koladyne and its tributaries in Mizoram and comparison with specimens in ZSI, Kolkata and in MUMF. WV supervision in establishing new species and discuss taxonomic status. 
Appendix 1. Biometric data of Barilius profundus sp. nov.

\begin{tabular}{|c|c|c|c|c|c|c|c|c|c|c|c|c|c|}
\hline \multirow{2}{*}{ Measurements } & \multirow{2}{*}{$\begin{array}{c}\text { Holotype } \\
\text { MUMF } \\
27001\end{array}$} & \multicolumn{12}{|c|}{ Paratypes $(\mathrm{N}=12)$} \\
\hline & & $\begin{array}{l}\text { MUMF } \\
27002\end{array}$ & $\begin{array}{l}\text { MUMF } \\
27003\end{array}$ & $\begin{array}{l}\text { MUMF } \\
27004\end{array}$ & $\begin{array}{l}\text { MUMF } \\
27005\end{array}$ & $\begin{array}{l}\text { MUMF } \\
27021\end{array}$ & $\begin{array}{l}\text { MUMF } \\
27022\end{array}$ & $\begin{array}{l}\text { MUMF } \\
27023\end{array}$ & $\begin{array}{l}\text { MUMF } \\
27024\end{array}$ & $\begin{array}{l}\text { MUMF } \\
27025\end{array}$ & $\begin{array}{l}\text { MUMF } \\
27026\end{array}$ & $\begin{array}{l}\text { MUMF } \\
27027\end{array}$ & $\begin{array}{l}\text { MUMF } \\
27028\end{array}$ \\
\hline $\begin{array}{l}\text { Standard } \\
\text { length }\end{array}$ & 71.1 & 67.7 & 55.2 & 61.5 & 54.5 & 69.9 & 64.1 & 60.9 & 64.6 & 58.9 & 69.8 & 50.9 & 55.2 \\
\hline $\begin{array}{l}\text { Body depth } \\
\text { at dorsal fin } \\
\text { origin }\end{array}$ & 22.8 & 23.5 & 20.3 & 22.0 & 18.6 & 23.9 & 23.4 & 22.4 & 24.1 & 21.3 & 25.6 & 17.1 & 18.5 \\
\hline Head length & 13.2 & 12.6 & 11.2 & 12.6 & 11.4 & 13.5 & 12.7 & 12.2 & 12.4 & 11.5 & 13.3 & 10.7 & 10.6 \\
\hline $\begin{array}{l}\text { Predorsal } \\
\text { length }\end{array}$ & 43.2 & 39.9 & 34.6 & 38.7 & 32.5 & 42.0 & 39.5 & 36.3 & 39.9 & 37.7 & 42.1 & 30.9 & 33.1 \\
\hline $\begin{array}{l}\text { Prepelvic } \\
\text { length }\end{array}$ & 37.2 & 37.1 & 30.8 & 38.3 & 29.5 & 38.0 & 36.7 & 35.0 & 36.5 & 33.3 & 37.9 & 23.3 & 30.4 \\
\hline $\begin{array}{l}\text { Pre-anus } \\
\text { length }\end{array}$ & 48.2 & 48.1 & 40.5 & 44.9 & 37.2 & 50.3 & 44.8 & 44.5 & 48.2 & 42.6 & 50.6 & 38.3 & 41.0 \\
\hline $\begin{array}{l}\text { Preanal } \\
\text { length }\end{array}$ & 50.2 & 50.9 & 40.7 & 46.9 & 40.0 & 51.1 & 48.5 & 45.0 & 48.9 & 43.8 & 50.6 & 38.3 & 41.0 \\
\hline $\begin{array}{l}\text { Prepectoral } \\
\text { length }\end{array}$ & 20.3 & 20.3 & 16.0 & 17.5 & 15.4 & 18.8 & 18.5 & 18.4 & 18.1 & 17.0 & 20.4 & 15.1 & 15.6 \\
\hline $\begin{array}{l}\text { Pectoral fin } \\
\text { length }\end{array}$ & 14.8 & 14.6 & 13.1 & 15.1 & 12.2 & 15.2 & 14.9 & 14.4 & 14.1 & 13.2 & 15.2 & 11.9 & 12.2 \\
\hline $\begin{array}{l}\text { Pelvic fin } \\
\text { length }\end{array}$ & 9.9 & 10.0 & 9.7 & 9.6 & 8.7 & 10.9 & 9.9 & 10.1 & 10.2 & 9.1 & 10.9 & 8.5 & 8.6 \\
\hline $\begin{array}{l}\text { Dorsal fin } \\
\text { height }\end{array}$ & 15.4 & 15.0 & 12.9 & 14.8 & 12.4 & 16.3 & 15.0 & 14.9 & 15.3 & 14.7 & 16.8 & 13.1 & 12.4 \\
\hline $\begin{array}{l}\text { Dorsal fin } \\
\text { base length }\end{array}$ & 11.6 & 10.5 & 8.4 & 10.0 & 8.8 & 10.7 & 11.0 & 10.0 & 11.1 & 10.3 & 12.1 & 7.6 & 8.7 \\
\hline Anal fin length & 11.8 & 11.7 & 10.1 & 11.4 & 10.6 & 12.3 & 12.0 & 11.4 & 11.4 & 10.8 & 13.8 & 10.4 & 10.2 \\
\hline $\begin{array}{l}\text { Caudal } \\
\text { peduncle length }\end{array}$ & 10.1 & 7.5 & 6.5 & 6.9 & 8.4 & 7.9 & 8.6 & 8.0 & 8.0 & 8.1 & 9.8 & 7.5 & 7.3 \\
\hline $\begin{array}{l}\text { Caudal peduncle } \\
\text { depth }\end{array}$ & 8.4 & 8.9 & 6.6 & 7.0 & 6.7 & 8.3 & 7.6 & 7.6 & 8.1 & 7.4 & 8.9 & 6.1 & 6.6 \\
\hline Snout length & 5.7 & 4.7 & 4.5 & 4.4 & 4.3 & 5.4 & 5.4 & 5.0 & 5.0 & 4.7 & 5.5 & 3.8 & 4.1 \\
\hline Eye diameter & 5.3 & 5.0 & 4.7 & 5.0 & 4.9 & 5.3 & 5.1 & 4.7 & 5.2 & 4.9 & 5.1 & 4.6 & 4.3 \\
\hline $\begin{array}{l}\text { Interorbital } \\
\text { distance }\end{array}$ & 6.6 & 6.4 & 5.6 & 5.7 & 5.4 & 7.1 & 6.3 & 6.1 & 6.1 & 5.9 & 7.1 & 5.1 & 5.4 \\
\hline $\begin{array}{l}\text { Max. Head } \\
\text { width }\end{array}$ & 8.9 & 8.3 & 6.6 & 8.9 & 7.6 & 10.7 & 9.2 & 8.4 & 9.9 & 7.4 & 10.2 & 6.7 & 6.9 \\
\hline $\begin{array}{l}\text { Head height at } \\
\text { supraoccipital }\end{array}$ & 15.7 & 15.5 & 12.5 & 15.1 & 12.8 & 16.5 & 16.2 & 14.5 & 15.7 & 14.1 & 18.2 & 12.4 & 12.8 \\
\hline \multicolumn{14}{|l|}{ Counts } \\
\hline $\mathrm{D}$ & $\mathrm{ii}, 71 / 2$ & ii, $71 / 2$ & $\mathrm{ii}, 71 / 2$ & ii, $71 / 2$ & ii, $71 / 2$ & ii, $71 / 2$ & ii, $71 / 2$ & ii, $71 / 2$ & $\mathrm{ii}, 71 / 2$ & ii, $71 / 2$ & $\mathrm{ii}, 71 / 2$ & ii, $71 / 2$ & ii, $71 / 2$ \\
\hline $\mathrm{P}$ & $\mathrm{i}, 11$ & $\mathrm{i}, 11$ & $\mathrm{i}, 11$ & $\mathrm{i}, 11$ & $\mathrm{i}, 11$ & $\mathrm{i}, 11$ & $\mathrm{i}, 11$ & $\mathrm{i}, 11$ & $\mathrm{i}, 11$ & $\mathrm{i}, 11$ & $\mathrm{i}, 11$ & $\mathrm{i}, 11$ & $\mathrm{i}, 11$ \\
\hline V & $\mathrm{i}, 8$ & $\mathrm{i}, 8$ & i, 8 & i, 8 & i, 8 & i, 8 & i, 8 & i, 8 & i, 8 & i, 8 & i, 8 & i, 8 & i, 8 \\
\hline$A$ & ii, $101 / 2$ & ii, $101 / 2$ & ii, $101 / 2$ & ii, $101 / 2$ & ii, $101 / 2$ & ii, $101 / 2$ & ii, $101 / 2$ & ii, $101 / 2$ & ii, $101 / 2$ & ii, $101 / 2$ & ii, $101 / 2$ & ii, $10 \frac{1}{2}$ & ii, $101 / 2$ \\
\hline C & i, $9+8, i$ & i, $9+8, \mathrm{i}$ & i, $9+8, i$ & $\mathrm{i}, 9+8, \mathrm{i}$ & i, 9+8, i & i, $9+8, i$ & i, $9+8, i$ & i, $9+8, i$ & i, 9+8, i & i, 9+8, i & i, $9+8, i$ & i, 9+8, i & i, 9+8, i \\
\hline L. I. & $32+2$ & $31+3$ & $30+3$ & $32+3$ & $30+3$ & $30+3$ & $32+2$ & $31+2$ & $31+3$ & $32+3$ & $32+3$ & $31+3$ & $30+3$ \\
\hline L.tr. & $\begin{array}{c}1 / 2 / 7 / 1 / \\
1 / 2\end{array}$ & $\begin{array}{c}1 / 2 / 7 / 1 / \\
1 / 2 \\
\end{array}$ & $\begin{array}{c}1 / 2 / 7 / 1 \\
11 / 2\end{array}$ & $\begin{array}{c}1 / 2 / 7 / 1 / \\
1 / 2 \\
\end{array}$ & $\begin{array}{c}1 / 2 / 7 / 1 / \\
1 / 2 \\
\end{array}$ & $\begin{array}{c}1 / 2 / 7 / 1 / \\
1 / 2 \\
\end{array}$ & $\begin{array}{c}1 / 2 / 7 / 1 \\
/ 1 / 2\end{array}$ & $\begin{array}{c}1 / 2 / 7 / 1 / \\
1 / 2 \\
\end{array}$ & $\begin{array}{c}1 / 2 / 7 / 1 / \\
1 / 2 \\
\end{array}$ & $\begin{array}{c}1 / 2 / 7 / 1 / \\
1 / 2\end{array}$ & $\begin{array}{c}1 / 2 / 7 / 1 / \\
1 / 2\end{array}$ & $\begin{array}{c}1 / 2 / 7 / 1 / \\
1 / 2 \\
\end{array}$ & $\begin{array}{c}1 / 2 / 7 / 1 / \\
1 / 2 \\
\end{array}$ \\
\hline Predorsal scales & 18 & 18 & 18 & 18 & 18 & 17 & 17 & 18 & 17 & 18 & 17 & 18 & 18 \\
\hline $\begin{array}{l}\text { Circumpedun- } \\
\text { cular scales }\end{array}$ & 12 & 12 & 12 & 12 & 12 & 12 & 12 & 12 & 12 & 12 & 12 & 12 & 12 \\
\hline $\begin{array}{l}\text { Dark blue bars } \\
\text { on body }\end{array}$ & 8 & 8 & 8 & 8 & 9 & 10 & 7 & 7 & 7 & 10 & 7 & 9 & 7 \\
\hline
\end{tabular}

